\title{
ANALISIS KESALAHAN PENYELESAIAN SOAL CERITA BERDASARKAN KRITERIA WATSON
}

\author{
Fitria Nur Kusti Aisyah ${ }^{1}$, Sri Hariyani ${ }^{2}$, Riski Nur Istiqomah Dinullah ${ }^{3}$ \\ 1,2,3 Universitas Kanjuruhan Malang \\ Corresponding Author: sribariyani@unikama.ac.id
}

\begin{abstract}
This study aims to analyze errors by students in problem-solving of mathematical story based on Watson criteria. The subjects of this study were two bigh-ability students, two moderate-ability students, and two low-ability students. This study at class VII-C SMP NU Sunan Giri Kepanjen. The instruments used are written tests and interviews - the validity of the data checking by the triangulation of sources that compare test results and interview data. Data analysis used is data reduction, data presentation, and conclusions. The students' errors were analyzed using the Watson error category, which consisted of 8 errors. The results showed that based on Watson's error criteria, the mistakes that occurred were inaccurate data, improper procedures, skill hierarchy problems, missing data, nothing manipulation directly, conflict level response, missing conclusions and in addition to the seven categories. The results of this study are expected to be an input for the teacher about the types of student's errors at SMP Sunan Giri Kepanjen.
\end{abstract}

Keywords: Student errors, Problem solving, Watson criteria.

How to cite: Hariyani, S., Aisyah, F., \& Dinullah, R. (2019). Analisis Kesalahan Penyelesaian Soal Cerita Berdasarkan Kriteria Watson. JRPM (Jurnal Review Pembelajaran Matematika), 4(1), 11-22.

\section{PENDAHULUAN}

Matematika merupakan ilmu pengetahuan yang mempelajari sesuatu yang abstrak yaitu fakta, konsep, operasi dan prinsip yang mempunyai karakter (Tasekeb, 2017). Pada mata pelajaran matematika semua materi yang dipelajari memiliki hubungan satu sama lain, seperti yang dikemukakan Runtukahu dan Kondou (2014) bahwa matematika adalah ilmu yang terstruktur, dengan kemampuan awal merupakan prasyarat bagi kemampuan berikutnya. Hal ini sejalan dengan Abdurrahman (dalam Purwati \& Haryanto, 2016) mengemukakan bahwa untuk mencapai prestasi akademik yang memuaskan, seorang anak memerlukan penguasaan keterampilan prasyarat.

Matematika merupakan salah satu bidang studi yang mengajak peserta didik untuk berpikir (Subanji, 2015). Matematika selalu identik dengan konsep dan peserta didik akan selalu dituntut untuk memahami konsep-konsep yang ada pada matematika (Andriani, Suastika, \& Sesanti, 2017). Salah satu materi yang dituntut untuk dipahami oleh peserta didik yaitu bilangan pecahan. Materi bilangan pecahan yang terdiri dari penjumlahan, pengurangan, perkalian, dan pembagian harus benar-benar dipahami dari segi konsep, prosedur serta keterampilan dalam berhitung guna menghindari adanya kesalahan-kesalahan 
yang dialami peserta didik ketika menyelesaikan masalah terkait dengan pecahan (Saparwadi, Purnawati, \& Erlian, 2017).

Kenyataan di lapangan menunjukkan bahwa masih banyak peserta didik yang belum mengerti dan menguasai konsep pecahan dengan benar, sehingga mengalami kesulitan dalam menyelesaikan soal-soal pokok bahasan pecahan (Ramlah, Bennu, \& Paloloang, 2016; Untari, 2013). Berdasarkan hasil diskusi dengan guru matematika dan observasi yang dilakukan di SMP NU Sunan Giri Kepanjen, peserta didik mengalami kesulitan dalam memecahkan soal cerita. Peserta didik cenderung menyelesaikan soal matematika dengan hanya menerapkan rumus tanpa bersusah payah memaknai soal cerita. Peserta didik hanya meniru prosedur penyelesaian yang dicontohkan oleh guru (Hariyani, 2018). Kondisi ini menyebabkan peserta didik merasakan kebingungan dalam menyelesaikan soal-soal cerita tersebut, terutama dalam memahami isi soal cerita.

Menurut Wahyuni (dalam Marlina, 2013) rendahnya kemampuan peserta didik dalam mengerjakan soal cerita dapat dilihat dari banyaknya kesalahan peserta didik dalam mengerjakan soal-soal cerita. Kesalahan peserta didik dalam mengerjakan soal tersebut dapat menjadi salah satu petunjuk untuk mengetahui sejauhmana siswa menguasai materi (Salle \& Pai'pinan, 2016), sehingga kesalahan yang dilakukan peserta didik perlu dianalisis lebih lanjut agar memperoleh gambaran yang lebih rinci atas kelemahan-kelemahan peserta didik dalam menyelesaikan soal matematika (Wulandari, 2016).

Pada penelitian ini, digunakan kriteria Watson untuk mengidentifikasi kesalahan peserta didik pada setiap langkah penyelesaian. Kriteria kesalahan Watson dapat mengukur letak kemampuan kognitif peserta didik dalam mengerjakan soal-soal tes. Kriteria kesalahan menurut Watson terdiri dari 8 kesalahan, yaitu data tidak tepat, prosedur tidak tepat, masalah hierarki keterampilan, data hilang, manipulasi tidak langsung, konflik level respon, kesimpulan hilang dan selain tujuh kategori tersebut.

Berdasarkan hasil penelitian yang dilakukan oleh Huljannah (2015) diperoleh bahwa jenis-jenis kesalahan peserta didik dalam menyelesaikan soal matematika berdasarkan kriteria Watson adalah sebagai berikut: (1) subjek berkemampuan tinggi melakukan kesalahan prosedur tidak tepat yaitu salah dalam melakukan operasi aljabar dan masalah hirarki keterampilan yaitu kurangnya keterampilan yang dimiliki subjek; (2) subjek berkemampuan sedang melakukan kesalahan prosedur tidak tepat yaitu salah dalam melakukan operasi aljabar dan penarikan akar kuadrat, kesalahan data hilang yaitu tidak memahami sepenuhnya soal yang diberikan sehingga subjek tidak mendapatkan data dari 
soal, kesalahan manipulasi tidak langsung yaitu alasan subjek yang tidak logis dalam memperoleh jawaban dan kesalahan masalah hirarki keterampilan yaitu kurangnya keterampilan yang dimiliki subjek; (3) subjek berkemampuan rendah melakukan kesalahan kategori lain dalam menyelesaikan soal matematika yaitu tidak memberikan jawaban.

Keterkaitan penelitian ini dengan penelitian Huljannah adalah menggunakan analisis kesalahan kriteria Watson sedangkan letak perbedaannya yaitu pada bentuk soal. Penelitian sebelumnya menggunakan soal pembuktian pada materi Trigonometri, sedangkan penelitian ini menggunakan soal cerita pada materi pecahan. Hal ini sesuai dengan observasi dan diskusi dengan guru mata pelajaran bahwa peserta didik mengalami kesulitan dalam mengerjakan soal cerita. Berdasarkan pernyataan tersebut, maka dirasa perlu adanya pengidentifikasian kesalahan dalam mengerjakan soal cerita matematika khususnya pada materi pecahan.

\section{METODE PENELITIAN}

Jenis penelitian ini adalah penelitian deskriptif kualitatif. Penelitian ini dilaksanakan di SMP NU Sunan Giri Kepanjen. Subjek penelitian dipilih dari peserta didik kelas VII-C yang terdiri dari 6 peserta didik yaitu, 2 peserta didik pada kelompok kesalahan rendah, 2 peserta didik pada kelompok kesalahan sedang dan 2 peserta didik pada kelompok kesalahan tinggi. Penentuan kelompok kesalahan didasarkan pada banyak peserta didik yang teridentifikasi memiliki kesalahan sesuai dengan 8 kriteria Watson. Prosedur penyusunan instrumen tes dilakukan dengan langkah-langkah berikut: (1) pembuatan kisi-kisi soal pecahan, (2) penyusunan soal sesuai dengan kisi-kisi, (3) penyusunan alternatif jawaban dan pedoman penskoran, (4) validasi soal kepada dosen dan guru matematika, dan (5) revisi soal. Soal tes yang telah divalidasi berjumlah 3 soal uraian.

Wawancara dalam penelitian ini digunakan untuk melengkapi hasil pengumpulan data tentang kesalahan peserta didik dalam menyelesaikan soal cerita berdasarkan kriteria Watson. Penelitian ini menggunakan wawancara semi terstruktur, dimana subjek diwawancarai dengan memberikan pertanyaan yang sudah disiapkan, kemudian diperdalam satu persatu untuk mencari keterangan lebih lanjut sesuai kesalahan peserta didik. Wawancara dilakukan setelah pelaksanaan pekerjaan tes. Wawancara dilakukan pada 2 peserta didik untuk masing-masing kelompok yaitu kelompok rendah, sedang dan tinggi sesuai skor yang diperoleh. Instrumen dalam wawancara ini adalah pedoman wawancara dan catatan lapangan untuk melengkapi data hasil wawancara. 
Teknik analisis data yang digunakan dalam penelitian ini adalah reduksi data, penyajian data, dan penarikan kesimpulan. Pada tahap reduksi data, dilakukan seleksi informasi yang relevan dengan penelitian, memilih hal-hal pokok, memfokuskan pada hal yang penting, sehingga data-data yang diperoleh lebih jelas. Data yang diperoleh dapat mempermudah pengelompokan jenis kesalahan yang dilakukan peserta didik dalam menyelesaikan soal cerita berdasarkan kriteria Watson. Data yang diperoleh pada proses ini yaitu data hasil tes peserta didik. Penyajian data merupakan proses menampilkan atau memaparkan data secara sederhana dalam bentuk kalimat naratif dan tabel dengan maksud agar data yang diperoleh dapat digunakan oleh peneliti sebagai dasar untuk mengambil kesimpulan yang tepat. Pada tahap penarikan kesimpulan, data yang sudah disajikan dilakukan penafsiran kesimpulan. Berdasarkan hasil tafsiran kesimpulan dapat mendeskripsikan kesalahan peserta didik dalam menyelesaikan soal cerita berdasarkan indikator kesalahan kriteria Watson.

\section{HASIL DAN PEMBAHASAN}

Berdasarkan hasil tes tulis, peserta didik kemudian dikelompokkan menjadi tiga kelompok yaitu kelompok rendah, sedang, dan tinggi. Kemudian diambil 2 subjek pada masing-masing kelompok. Daftar pengelompokan hasil tes peserta didik disajikan pada Tabel 1.

Tabel 1. Pengelompokan Hasil Tes Soal Cerita Materi Bilangan Pecahan

\begin{tabular}{lcc}
\hline Kategori & Jumlah Peserta Didik & Kode Peserta Didik \\
\hline Kesalahan Rendah & 2 & $\mathrm{P}_{2}, \mathrm{P}_{12}$ \\
\hline Kesalahan Sedang & 7 & $\mathrm{P}_{7}, \mathrm{P}_{8}, \mathrm{P}_{13}, \mathrm{P}_{14}, \mathrm{P}_{17}, \mathrm{P}_{18}, \mathrm{P}_{19}$ \\
\hline Kesalahan Tinggi & 10 & $\mathrm{P}_{1}, \mathrm{P}_{3}, \mathrm{P}_{4}, \mathrm{P}_{5}, \mathrm{P}_{6} \mathrm{P}_{9}, \mathrm{P}_{10}, \mathrm{P}_{11}$, \\
& & $\mathrm{P}_{15}, \mathrm{P}_{16}$ \\
\hline
\end{tabular}

Kemudian dipilih 6 subjek untuk dilakukan wawancara. Berikut daftar peserta didik yang dipilih untuk dilakukan wawancara.

Tabel 2. Data Subjek Wawancara

\begin{tabular}{ccc}
\hline No. & Kode Subjek & Kategori \\
\hline 1 & $\mathrm{P}_{2}$ & Kesalahan Rendah \\
\hline 2 & $\mathrm{P}_{12}$ & Kesalahan Rendah \\
\hline 3 & $\mathrm{P}_{13}$ & Kesalahan Sedang \\
\hline 4 & $\mathrm{P}_{14}$ & Kesalahan Sedang \\
\hline 5 & $\mathrm{P}_{4}$ & Kesalahan Tinggi \\
\hline 6 & $\mathrm{P}_{5}$ & Kesalahan Tinggi \\
\hline
\end{tabular}

\section{Subjek $P_{2}$ yang mewakili kelompok kesalahan rendah.}

Hasil pekerjaan $\mathrm{P}_{2}$ dapat dilihat pada Gambar 1 berikut. 


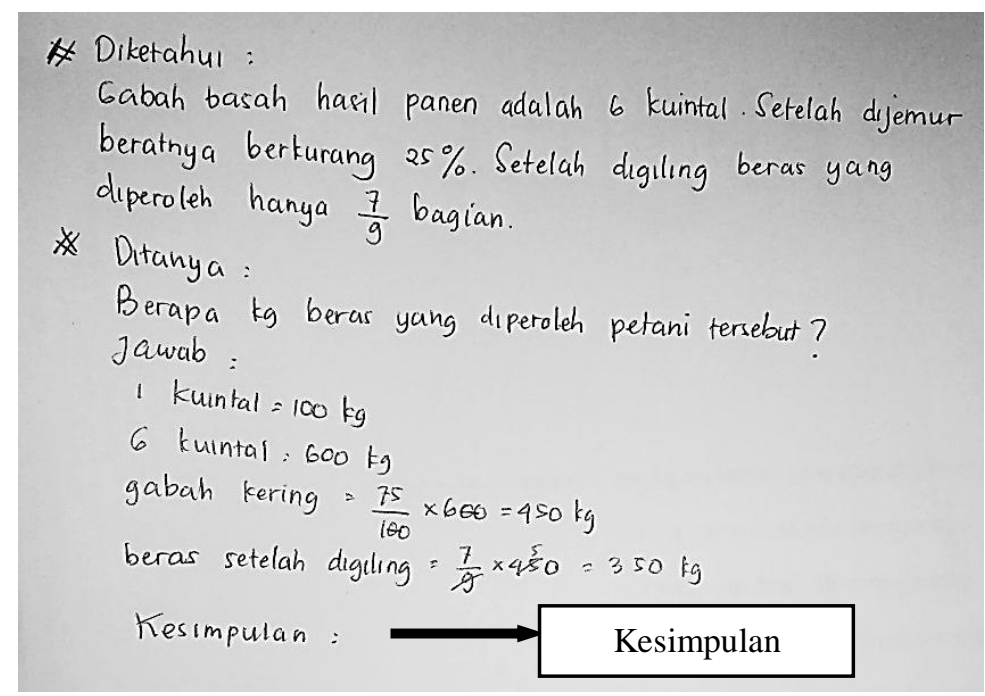

Gambar 1. Hasil Tes $P_{2}$ Terhadap Soal S1

Berdasarkan hasil pekerjaan $\mathrm{P}_{2}$, diperoleh bahwa $\mathrm{P}_{2}$ dapat mengerjakan soal nomor 1 dengan benar, tetapi ada beberapa kesalahan yang dilakukan. Hasil pekerjaan tersebut tampak bahwa $\mathrm{P}_{2}$ melakukan kesalahan data hilang dan kesimpulan hilang, seperti yang terlihat pada Gambar 1. Hasil analisis peneliti pada pekerjaan $\mathrm{P}_{2}$ dapat dilihat pada Tabel 3.

Tabel 3. Hasil Analisis Terhadap Soal $\mathrm{P}_{2}$

\begin{tabular}{cc}
\hline Kriteria Watson & Deskripsi Kesalahan \\
\hline Data tidak tepat & - \\
\hline Prosedur tidak tepat & - \\
\hline Masalah hierarki keterampilan & - \\
\hline Data hilang & $\begin{array}{c}\text { Pada soal nomor 1, kesalahan yang dilakukan oleh } \mathrm{P}_{2} \text { yaitu } \\
\text { tidak menuliskan cara untuk memperoleh persentase gabah } \\
\text { setelah dijemur yaitu } 75 \% . \mathrm{P}_{2} \text { langsung memasukkan data } 75 \\
\text { tersebut untuk mencari gabah kering. }\end{array}$ \\
\hline Konflik level respon & - \\
\hline Manipulasi tidak langsung & - \\
\hline Kesimpulan hilang & $\mathrm{P}_{2}$ tidak menuliskan kesimpulan pada akhir penyelesaian soal, \\
& meskipun $\mathrm{P}_{2}$ telah memperoleh hasil akhir. \\
\hline Selain kategori diatas & - \\
\hline
\end{tabular}

\section{Subjek $P_{13}$ yang mewakili kelompok kesalahan sedang.}

Hasil pekerjaan $\mathrm{P}_{13}$ dapat dilihat pada Gambar 2 berikut. 


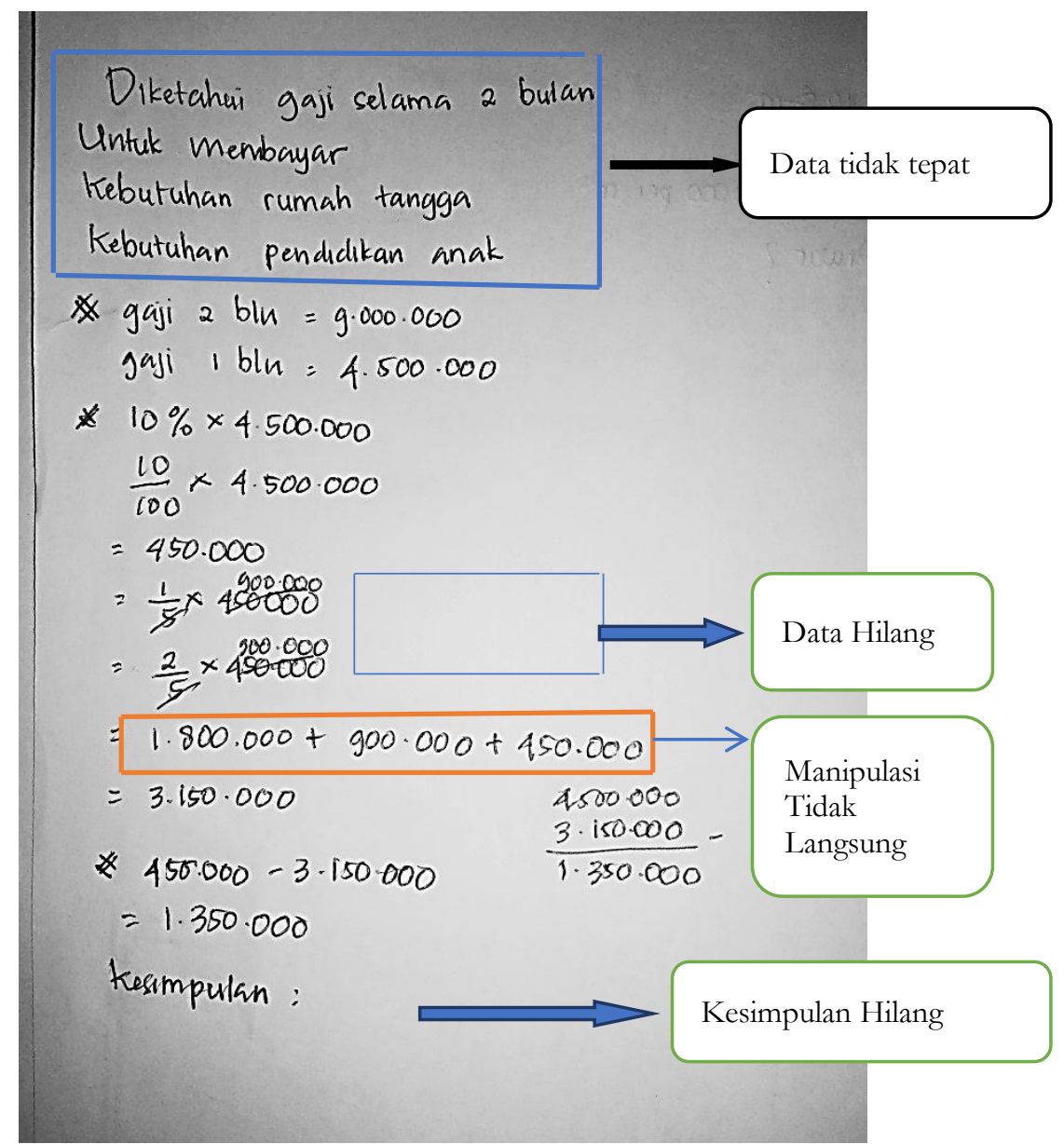

Gambar 2. Hasil Tes $P_{13}$ Terhadap Soal S2

Pada hasil pekerjaan $\mathrm{P}_{13}$, diperoleh bahwa $\mathrm{P}_{13}$ dapat mengerjakan soal nomor 2 dengan benar, tetapi ada beberapa kesalahan yang dilakukan. $\mathrm{P}_{13}$ melakukan kesalahan data hilang, manipulasi tidak langsung dan kesimpulan hilang, seperti yang terlihat pada Gambar 2. Hasil analisis peneliti pada pekerjaan $\mathrm{P}_{2}$ dapat dilihat pada Tabel 4 berikut ini.

Tabel 4. Hasil Analisis terhadap $\mathrm{P}_{13}$

\begin{tabular}{|c|c|}
\hline Kriteria Watson & Deskripsi Kesalahan \\
\hline Data tidak tepat & $\begin{array}{l}\text { Berdasarkan hasil pekerjaan } \mathrm{P}_{13} \text {, nampak bahwa } \mathrm{P}_{13} \text { telah mengerjakan soal } \\
\text { sesuai perintah soal, seperti terlihat pada Gambar } 2 \text {. Gambar } 2 \text { juga } \\
\text { menunjukkan bahwa } \mathrm{P}_{13} \text { hanya menuliskan diketahui yaitu untuk membayar } \\
\text { kebutuhan rumah tangga dan kebutuhan pendidikan anak, tanpa } \\
\text { menuliskan jumlah dari masing-masing kebutuhan. } \mathrm{P}_{13} \text { langsung menjawab } \\
\text { soal, setelah menuliskan apa yang diketahui, serta } \mathrm{P}_{13} \text { tidak menuliskan apa } \\
\text { yang ditanyakan pada soal. }\end{array}$ \\
\hline Prosedur tidak tepat & - \\
\hline $\begin{array}{c}\text { Masalah hierarki } \\
\text { keterampilan }\end{array}$ & - \\
\hline Data hilang & $\begin{array}{l}P_{13} \text { kehilangan data karena tidak lanjut melakukan proses perhitungan untuk } \\
\text { mencari kebutuhan rumah tangga }=\frac{1}{5} \times 450.000 \text { dan kebutuhan pendidikan } \\
\text { anak }=\frac{2}{5} \times 450.000 \text {, seperti yang terlihat pada Gambar } 2 \text {. }\end{array}$ \\
\hline Konflik level respon & - \\
\hline Manipulasi tidak langsung & Kesalahan yang dilakukan oleh $\mathrm{P}_{13}$ yakni ketika $\mathrm{P}_{13}$ mencari total \\
\hline
\end{tabular}




\begin{tabular}{cl}
\hline Kriteria Watson & \multicolumn{1}{c}{ Deskripsi Kesalahan } \\
\hline & pengeluaran 1 bulan yaitu nilai 1.800.000 + 900.000 + 450.000. Pada proses \\
& sebelumnya P13 sudah menuliskan cara untuk mencari nilai dari 450.000, \\
& yaitu perhitungan pada bagian mencari kebutuhan untuk membayar PDAM. \\
& Sedangkan 1.800.000 dan 900.000 dimunculkan tanpa melalui proses \\
& sebelumnya. Peserta didik menuliskan perhitungan pengeluaran kebutuhan \\
& rumah tangga yaitu 1.800.000 + 900.000 + 450.000 = 3.150.000. Hal ini \\
& dapat ditunjukkan pada Gambar 2. \\
\hline Kesimpulan hilang & P $_{13}$ tidak menuliskan kesimpulan dari data yang telah diperoleh. \\
\hline Selain kategori diatas & \\
\hline
\end{tabular}

\section{Subjek $\boldsymbol{P}_{4}$ yang mewakili kelompok kesalahan tinggi.}

Hasil pekerjaan $\mathrm{P}_{4}$ dapat dilihat pada Gambar 3 berikut.

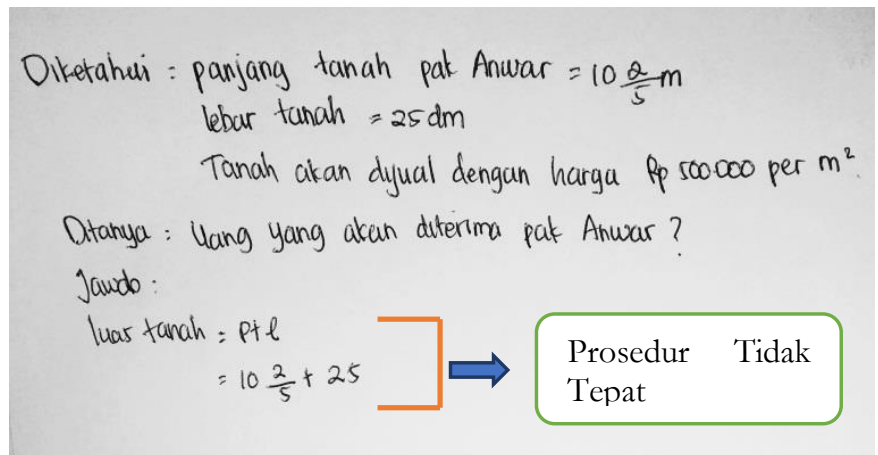

Gambar 3. Hasil Tes $P_{4}$ Terhadap Soal S3

Berdasarkan hasil pekerjaan $\mathrm{P}_{4}$ pada Gambar 3, dapat dikatakan bahwa $\mathrm{P}_{4}$ dapat mengerjakan soal nomor 3 bagian awal saja, karena terdapat beberapa kesalahan yang dilakukan. $\mathrm{P}_{4}$ melakukan kesalahan data tidak tepat, prosedur tidak tepat, data hilang, masalah hierarki keterampilan, konflik level respon, manipulasi tidak langsung dan kesimpulan hilang. Hasil analisis peneliti pada pekerjaan $\mathrm{P}_{2}$ dapat dilihat pada tabel berikut ini.

Tabel 5. Hasil Analisis Terhadap $\mathrm{P}_{4}$

\begin{tabular}{ll}
\hline Kriteria Watson & \multicolumn{1}{c}{ Deskripsi Kesalahan } \\
\hline Data tidak tepat & $\mathrm{P}_{4}$ salah dalam memasukkan data ke variabel yaitu $10 \frac{2}{5}+25$ \\
& seharusnya $10 \frac{2}{5} \times 2,5$. \\
\hline Prosedur tidak tepat & $\mathrm{P}_{4}$ salah dalam menentukan rumus luas tanah yaitu $\mathrm{p}+1$, \\
& seharusnya $\mathrm{p} \times 1$, sehingga $\mathrm{P}_{4}$ tidak menyelesaikan dengan \\
& prosedur yang tepat, seperti yang terlihat pada Gambar 3. \\
\hline Masalah hierarki keterampilan & $\mathrm{P}_{4}$ terlihat ada kesalahan dalam melakukan perhitungan. \\
& Kesalahan terlihat pada awal pekerjaan yaitu $10 \frac{2}{5}+25, \mathrm{P}_{4}$ tidak \\
& dapat melakukan perhitungan sampai tahap akhir penyelesaian. \\
\hline Data hilang & $\mathrm{P}_{4}$ telah menuliskan langkah awal yang akan digunakan dalam \\
& menyelesaikan soal tersebut, meskipun prosedur yang akan \\
& digunakan tidak tepat. Namun peserta didik tidak menyelesaikan \\
& soal tersebut sampai tahap akhir. \\
\hline Konflik level respon & $\mathrm{P}_{4}$ melakukan kesalahan pada kriteria tersebut, $\mathrm{P}_{4}$ tidak dapat \\
& mengerjakan soal sampai tahap akhir. \\
\hline Manipulasi tidak langsung & $\mathrm{P}_{4}$ tidak dapat melanjutkan pekerjaan soal tersebut. \\
\hline Kesimpulan hilang & $\mathrm{P}_{4}$ tidak dapat menuliskan kesimpulan akhir. \\
\hline
\end{tabular}


Kesalahan data tidak tepat terjadi karena peserta didik yang kurang memahami soal. Oleh karena itu, peserta didik tidak dapat menuliskan data atau informasi pada soal. Selain itu, peserta didik kurang teliti dalam membaca soal, sehingga data yang digunakan tidak tepat. Sejalan dengan Silitonga \& Febrian (2016) bahwa peserta didik tidak mampu memahami maksud dari permasalahan yang dihadapinya karena kurang kesiapan dalam mengikuti tes soal uraian.

Kesalahan peserta didik ada juga yang tidak melanjutkan proses pekerjaan soal sampai tahap akhir walaupun peserta didik sudah menuliskan prosedur awal. Peserta didik tidak melanjutkan proses pekerjaan karena tidak yakin dengan rumus awal yang di tulis. Hal ini sesuai dengan Khasanah dan Sutama (2015) menyatakan bahwa peserta didik tidak menguasai konsep matematika yang dipelajari dan peserta didik lupa rumus yang digunakan saat mengerjakan soal.

Penyebab peserta didik melakukan kesalahan masalah hierarki keterampilan karena peserta didik kurang teliti dalam mengerjakan soal yang diberikan. Hal ini ditandai bahwa peserta didik telah melakukan perhitungan, namun hasil yang diperoleh mengalami kesalahan. Sejalan dengan Wahyuningtias (2018) menyatakan bahwa peserta didik kurang teliti dalam menghitung dan peserta didik salah dalam menghitung karena tergesa-gesa.

Peserta didik melakukan kesalahan data hilang karena peserta didik kehilangan data dalam menyelesaikan soal. Hal ini terjadi dikarenakan peserta didik kurang teliti dan terburu-buru dalam mengerjakan soal. Sari (2016) menyatakan bahwa kesalahan data hilang menunjukkan adanya ketidaktepatan data dan kurang teliti dalam menyelesaikan soal dengan kriteria Watson.

Kesalahan yang dilakukan peserta didik yaitu menuliskan data pada proses pekerjaan selanjutnya, meskipun pada tahap sebelumnya peserta didik tidak menuliskan data tersebut. Hal ini dikatakan sebagai manipulasi tidak langsung karena data tiba-tiba ada pada tahap selanjutnya. Peserta didik merasa kurang waktu dalam mengerjakan soal (Suwarto, 2013).

Peserta didik melakukan kesalahan konflik level respon karena peserta didik kurang memahami bentuk soal dan kebingungan pada proses pekerjaan selanjutnya, sehingga peserta didik tidak mengerjakan soal sampai tahap menemukan hasil. Penyelesaian soal yang dikerjakan peserta didik yaitu langsung menjadikan hasil akhir, meskipun pekerjaan belum selesai sampai tahap akhir. Hal ini didukung oleh Hastuti, Surantoro, dan Rahardjo (2012) menyatakan bahwa peserta didik tidak membaca petunjuk mengerjakan soal, peserta 
didik kurang paham dengan apa yang ditanyakan soal dan peserta didik kurang latihan soal yang bervariasi.

Kesalahan kesimpulan hilang yang dilakukan peserta didik, yaitu tidak menuliskan kesimpulan pada akhir jawaban, meskipun peserta didik telah menemukan hasil akhir dari penyelesaian soal. Peserta didik ada juga yang memberikan kesimpulan, namun tidak sesuai yang dimaksud oleh soal yang diberikan. Selain itu, ada juga peserta didik yang tidak memberikan kesimpulan, karena tidak selesai dalam mengerjakan soal. Sejalan dengan Puspita (2016) menyatakan bahwa peserta didik melakukan kesalahan dengan tidak menuliskan kesimpulan ataupun menuliskan kesimpulan namun salah.

Pada kesalahan ini dapat diartikan bahwa peserta didik tidak menjawab soal sama sekali atau menuliskan ulang soal. Kesalahan pada kriteria ini adalah kemampuan memahami maksud soal yang rendah. Sesuai dengan Sahriah, Muksar, dan Lestari (2012) menyatakan bahwa kesalahan siswa dalam menyelesaikan soal matematika adalah tidak menjawab soal. Peneliti menganalisis, subjek yang diambil tidak ada yang melakukan kesalahan selain ketujuh kategori diatas, karena peserta didik telah menjawab soal meskipun mengalami kesalahan.

\section{SIMPULAN DAN SARAN}

Berdasarkan hasil penelitian dan pembahasan tentang analisis kesalahan peserta didik dalam menyelesaikan soal cerita bilangan pecahan berdasarkan kriteria Watson di kelas VII SMP NU Sunan Giri Kepanjen, maka dapat disimpulkan bentuk kesalahan peserta didik adalah sebagai berikut: (1) Kesalahan data tidak tepat yang dilakukan peserta didik yaitu tidak menuliskan data yang diketahui dan ditanyakan, tidak menuliskan data yang ditanyakan dan diketahui dengan tepat dan salah memasukkan data ke variabel; (2) Kesalahan peserta didik pada prosedur tidak tepat yaitu tidak dapat mengerjakan soal sampai tahap akhir walaupun sudah menentukan langkah awal untuk menyelesaikan soal yang diberikan serta salah dalam menentukan rumus untuk menyelesaikan soal; (3) Kesalahan masalah hierarki keterampilan yang dilakukan peserta didik yaitu tidak dapat menyelesaikan perhitungan dalam mengerjakan soal dan salah dalam menghitung penyelesaian; (4) Kesalahan data hilang yaitu kehilangan satu data atau lebih sehingga penyelesaian tidak benar; (5) Kesalahan manipulasi tidak langsung yang dilakukan peserta didik yaitu tidak menuliskan prosedur yang digunakan untuk menemukan hasil pada setiap langkah pekerjaan, namun peserta didik dapat menemukan hasil yang akan digunakan untuk 
proses selanjutnya dan juga dapat menemukan hasil akhir tanpa adanya proses dalam mengerjakan soal; (6) Kesalahan konflik level respon yaitu dalam menyelesaikan soal dalam proses penyelesaian soal berikutnya. Hal itu menyebabkan peserta didik tidak dapat menemukan hasil akhir sesuai yang ditanyakan pada soal yang telah diberikan; (7) Kesalahan kesimpulan hilang yang dilakukan peserta didik yaitu tidak menuliskan kesimpulan meskipun peserta didik sudah menemukan hasil akhir, peserta didik menuliskan kesimpulan namun tidak tepat dan peserta didik tidak memberikan kesimpulan karena tidak dapat menyelesaikan soal sampai menemukan hasil akhir. Selain ketujuh kategori ini dalam penelitian ini terdapat kesalahan kategori lainnya, yaitu peserta didik tidak menjawab soal yang diberikan.

Berdasarkan hasil penelitian yang dilakukan, saran yang dapat diberikan, yaitu (1) dapat digunakan untuk mengetahui bentuk kesalahan yang dilakukan oleh peserta didik pada pokok bahasan pecahan dan (2) dapat dilakukan kajian dan pengembangan lebih detail tentang instrumen penelitian yang lebih baik, sehingga kesalahan peserta didik dapat teridentifikasi.

\section{DAFTAR RUJUKAN}

Andriani, T., Suastika, I., \& Sesanti, N. (2017). Analisis Kesalahan Konsep Matematika Siswa dalam Menyelesaikan Soal Trigonometri Kelas X TKJ SMKN 1 Gempol Tahun Pelajaran 2016/2017. Pi: Mathematics Education Journal, 1(1), 34-39. DOI: https://doi.org/10.21067/pmej.v1i1.1998.

Hariyani, S. (2018). Errors Identification In Solving Arithmetic Problems. In Proceedings of the Annual Conference on Social Sciences and Humanities - Volume 1: ANCOSH, ISBN 978989-758-343-8, pages 357-360. DOI: https://doi.org/10.5220/0007420603570360.

Hastuti, I., Surantoro \& Rahardjo D. T. (2012). Analisis Kesalahan dalam Menyelesaikan Soal Materi pokok Kalor pada Siswa Kelas X SMA. Jurnal Materi dan pembelajaran Fisika, 2, 1-11.

Huljannah, M., Sugita, G., Anggraini. (2015). Analisis Kesalahan Siswa dalam Menyelesaikan Soal Persamaan dan Identitas Trigonometri Berdasarkan Kriteria Watson di Kelas X SMA Al-Azhar Palu. Aksioma: Jurnal Pendidikan Matematika, 4(2), 164-176.

Khasanah, U. \& Sutama. (2015). Kesulitan Menyelesaikan Soal Matematika pada Siswa SMP. In Prosiding Seminar Nasional Pendidikan Matematika. Hal. 79-89. Diakses dari https://publikasiilmiah.ums.ac.id/bitstream/handle/11617/6131/9 Ummi\%20Khas anah $\% 2079$ 89.pdf? sequence $=1$ \&is Allowed $=\mathrm{y}$. 
Marlina, L. (2013). Penerapan Langkah Polya dalam Menyelesaikan Soal Cerita Keliling dan Luas Persegi Panjang. Jurnal Elektronik Pendidikan Matematika Tadulako, 1(1): 43-42.

Purwati \& Haryanto, D. S. (2016). Analisis Kesalahan Siswa Dalam Menyelesaikan Soal Cerita Bilangan Pecahan Kelas VIII SMP 19 Manokwari. In Prosiding Seminar Nasional Vol. 3 No. 1, Palopo: 18 November 2017. hal. 130-137.

Puspita, R. A. (2016). Deskripsi Kesalahan Siswa Kelas IX SMP Pada Materi Sistem Persamaan Linier Dua Variabel Berdasarkan Klasifikasi Watson. Skripsi Tidak Dipublikasikan. Universitas Kristen Satya Wacana Salatiga. Tersedia dari http://repository.uksw.edu/bitstream/123456789/14601/2/T1 202013075 Full\%2 0text.pdf.

Ramlah, Bennu, S., \& Paloloang, B. (2016). Analisis Kesalahan Siswa dalam Menyelesaikan Soal Penjumlahan dan Pengurangan Pecahan di Kelas VII SMPN Model Terpadu Madani. Jurnal Ilmiah Pendidikan Matematika, 1(2), 182-194. DOI: http://dx.doi.org/10.26877/jipmat.v1i2.1245

Runtukahu, J. T \& Kondou, S. (2014). Pembelajaran Matematika Dasar Bagi Anak Berkesulitan Belajar. Yogyakarta: Ar-Ruzz Media

Sahriah, S., Muksar, M., \& Lestari, T. E. (2012). Analisis Kesalahan Siswa dalam Menyelesaikan Soal Matematika Materi Operasi Pecahan Bentuk Aljabar Kelas VII SMP Negeri 2 Malang. Retrieved from http://jurnalonline.um.ac.id/data/artikel/artikel9EEC8FEB3F87AC825C375098E45CB689.pdf.

Salle, N. \& Pai'pinan, M. (2016). Analisis Kesalahan Siswa dalam Menyelesaikan Soal Matematika pada Topik Keliling dan Luas Lingkaran di Kelas VIII C SMP YPK Hedam Semester Genap. Jurnal Imiah Matematika dan Pembelajarannya, 3(1), 23-30.

Saparwadi, L., Purnawati, B., \& Erlian, P. (2017). Kesalahan Siswa dalam Menyelesaikan Soal Operasi Penjumlahan pada Bilangan Pecahan dan Reversibilitas. Jurnal Pendidikan Matematika, 3(2), 60-66. DOI: http://dx.doi.org/10.33474/jpm.v3i2.715

Sari, I. W. (2018). Analisis Kesalahan Mahasiswa dalam Menyelesaikan Soal Trigonometri Berdasarkan Kriteria Watson. Jurnal Widyaloka IKIP Widya Darma, 5(2):139-146.

Silitonga, N., \& Febrian, F. (2017). Penyelesaian Masalah Bangun Datar Siswa Kelas VII: Kesalahan dan Kategorisasinya. Jurnal Gantang, 1(2), 57-68. https://doi.org/10.31629/jg.v1i2.54

Subanji. (2010). Dasar-dasar Evaluasi Pembelajaran. Yogyakarta: Graha Ilmu.

Suwarto. (2013). Pengembangan Tes Diagnostik dalam Pembelajaran. Yogyakarta: Pustaka Belajar.

Tasekeb, D. (2017). Analisis Kesalahan Siswa Kelas VIII dalam Menyelesaikan Soal Tentang Luas Lingkaran Berdasarkan Kriteria Watson. Tersedia dari http://repository.uksw.edu/bitstream/123456789/14616/2/T1_202013094_Full\%2 0text.pdf. 
Analisis Kesalahan Penyelesaian ...

Untari, E. (2013). Diagnosis Kesulitan Belajar Pokok Bahasan Pecahan pada Siswa Kelas V Sekolah Dasar. Media Prestasi, 12(2), 1-8.

Wahyuningtias, S. (2018). Analisis Kesalahan dalam Menyelesaikan Soal Cerita Pokok Bahasan Pecahan Menurut Kategori Watson pada Siswa Kelas VA SDN Tegal Gede 01 Jember. Tersedia dari http://repository.unej.ac.id/handle/123456789/87889. 